International Journal of Language Education

Volume 5, Number 2, 2021, pp. 89-101

ISSN: 2548-8457 (Print) 2548-8465 (Online)

Doi: https://doi.org/10.26858/ijole.v5i2.16357

\title{
Career Awareness in the Study of Malay Language Program
}

\author{
Zuraini Jusoh \\ Universiti Putra Malaysia, Malaysia \\ Email: zurainijusoh@upm.edu.my \\ Rozita Radhiah Said \\ Universiti Putra Malaysia, Malaysia \\ Email: radhiahrozita@upm.edu.my \\ Norazlina Hj. Mohd Kiram \\ Universiti Putra Malaysia, Malaysia \\ Email:noraz@upm.edu.my
}

Received: 20 November 2020

Reviewed: 4 January 2021-3 March 2021

Accepted: 3 May 2021

\begin{abstract}
Awareness of the career to be pursued can be present as early as childhood and can vary according to knowledge and interest. Most of today's children are more focused on achieving excellence in education, but still vague in the career that will be pursued. This situation persisted when they continued their studies at higher education and they realized that the choice of field of study was not in line with their ambitions. Usually, these children choose a field based on their results rather than settling for the required degree for the field of interest. Therefore, this study was conducted to determine the extent of students' understanding of the scope and career prospects in Malay language. Students were distributed with a set of questionnaires containing 54 items using ordinal scales of semantic difference types. The findings of the study showed that $34(56.7 \%)$ of the students studied chose this field of study as the main choice. Students also showed a high level of knowledge about careers in the Malay language which they studied $(\mathrm{M}=3.92 ; \mathrm{SD}=0.57)$. Students have also listed a total of 14 careers in the field of Malay language they are familiar with.
\end{abstract}

Keywords: Career awareness; career scope; career potential; Malay language field; higher education students

\section{Introduction}

Studies in the Malay language at the tertiary level are offered in some public universities such as Universiti Putra Malaysia (UPM), Universiti Kebangsaan Malaysia (UKM), Universiti Sains Malaysia (USM), Universiti Teknologi Mara (UiTM), Universiti Malaya (UM), Universiti Pendidikan Sultan Idris (UPSI), and Universiti Malaysia Sarawak (UNIMAS). This field of study program uses the term Malay Language or Malay Linguistics. At Universiti Putra Malaysia (UPM), the program is offered under the Malay Language Department at the Faculty of Modern Language and Communication, with the name of Bachelor of Arts Malay Language and 
Linguistics with honors. Students must complete 125 credit hours for three years and a half to qualify for graduation.

The offer of language fields at some in these public universities indicates that there is a need to deepen this national language and career opportunities are wide open. However, the perception of the public that the field of language is less economical and easy to master (Razak, 2007) makes students who studied this field feel inferior because their careers are often underestimated. History, on the other hand suggested that the Malay language has become a separate field of study and the focus of study in the colonial times (Abd Wahab et al., 2016). However, the attitude of people who fail to appreciate the position of Malay as the national language and openly questioned it as the country's official language (Hameed, 2016), making this area uneventful. Even worse, the students who studied this field themselves cannot appreciate the value of the official language of this country. As proposed by Esa et al. (2002), you should not let yourself lose confidence in the ability of the Malay language while others recognize it.

Confidence in the potential of the Malay language should not be disputed. This is because the Malay language has the largest number of speakers in the world. The number of speakers is more than 250 million and is the national language in four countries, namely Malaysia, Indonesia, Brunei and Singapore (Musa et. al., 2014). In fact, the Malay language is spoken by the Malay population in Southern Thailand, Philippines, Cambodia, Vietnam, Sri Lanka, South Africa and the other as the Malay diaspora (Takari, 2013). Now, the Malay language has reached a high position as a modern language, namely as a scientific language, the language of culture and literary language of the highest quality (Md Idris, 2013).

The development of the Malay language has gone through several stages, namely the ancient Malay language, classical Malay and new Malay (Awang, 2020) which has made the Malay language as a whole. The development of Malay language does not only serve as a mere communication tool, but it also applies across multiple disciplines (Abdul Rashid \& Abdullah, 2015). Now, the development of the Malay language can be observed with the establishment of the Chair of Malay Studies at the leading universities of the world and studied extensively. There are over 140 higher education institutions in over 50 countries around the world that offered courses in Malay, which is in the United States, United Kingdom, Japan, China, Russia, the Netherlands, Germany, Egypt, Iran and Pakistan (Ismail \& Subramaniam, 2017). The situation proves that the Malay language has a high potential and prospects either as areas that need to be studied, or even in providing diverse opportunities.

\section{Literature review}

Understanding and awareness of the career to be pursued should have been revealed since school. It is not only the parents who need to play a role in this, but also the school as a formal educational institution. This is because career education involves structured teaching and learning activities to provide a platform for students to understand their potential, work environment and improve their specialized skills in making future career choices (Mahmud et. al., 2016). Early exposure allows students to make initial planning by adapting subject choices to their desired career. On the other hand, what is observed in the current scenario of students in this country is, they are just learning without knowing the direction or goal of the job that they will pursue in the future.

A study conducted by the Economic Action Council (EAC) also supports this opinion when it thinks that one of the factors that make it difficult for graduates to get a job is due to lack of awareness about the existence of various job opportunities (Ismail, 2012). Society often assumes 
that language graduates have limited career opportunities. For example, among the career fields that are often associated with the Malay language is as a teacher. To become teachers, graduates need to take advanced courses to enable them to be eligible to be appointed as educators. Graduates who are interested in becoming lecturers need to continue their studies at the master's and doctoral level. This happens because of their lack of knowledge about the diversity of jobs in the Malay language field. Supposedly, the Malay language offers comprehensive employment opportunities in moving the industry employment (Ahmad, 2013). Therefore, graduates need to equip themselves with language knowledge and soft skills that have been absorbed throughout their studies. This is in line with the opinion of Ismail (2012) who said that having knowledgeable and highly skilled human capital is the most important factor for Malaysia to transform the economy towards achieving the status of a developed and high-income country by 2020.

In addition, the Malay language also has the potential to become the dominant language of the nobles (Esa et al., 2002). Malay language is also one of the important things in wills of the Malay rulers, as it was set as the national language, at once appointed as the official language for education and state administration (Hassan, 2018). Language serves as a vehicle for the acquisition of knowledge (Sariyan, 2009) and a tool as well as a vehicle for the formation and transfer of the nation's memory (Hassan, 2009). Therefore, the field of language should not be ignored and set aside because without language, knowledge cannot be acquired and developed.

This is also in line with the continuous efforts of Malay corporate developers in the country, the Dewan Bahasa dan Pustaka (DBP). DBP continues to increase efforts to put the Malay language as one of the major languages of the world, especially with the potential of Malaysia's international education, tourism centers and career centers that attract foreigners (Sariyan, 2020). This situation is certain to open up a variety of jobs to graduates in Malay language studies. Accordingly, students majoring in Malay language must also be convinced of the potential of the Malay language and improve their soft skills to enable graduates of the field of language to also compete in the world of work. These arguments has proven that Malay graduates will not be missed to build brilliant careers. The issue here is the ability of Malay graduates to develop their potential in order to obtain a desired career. The problem here is when these undergraduate students are not confident in the use of their degree in choosing a career (Ali et al., 2016). This situation may be due to the specialization is not of their choice or they do not know the diversity of careers in the field studied. Therefore, career formation should be implemented from the beginning to enable appropriate educational planning to be done. Therefore, the notion that the degree obtained is only a phase that needs to be passed in life and it does not make the degree and competency obtained in the university as an important criterion in determining the career field (Ali et al., 2016) irrelevant. Ideally, students earn a career in the field they are studying. This is because university studies are the highest level of study and are able to provide graduates in the career market that is appropriate to their field of study.

A similar case occurs with the Malay language studies. It should not be an issue for Malay language graduates not to get job opportunities or for this program not to be an option. The potential of this field is very wide, but its scope is narrowed by its own community. For example, the political scenario of the country. Policy changes made by the introduction of PPSMI in 2003 was a blow to public's confidence in the policy and the preservation of Malay as the language of science (Adam, 2014). Therefore, efforts should be made by various parties, including graduates of this field to increase the prestige of the Malay language with confidence and awareness of careers in the Malay language. 


\section{Methodology}

Research about career awareness among students of the Bachelor of Arts in Malay Language and Linguistics (BLM) in the Faculty of Modern Language and Communication, Universiti Putra Malaysia was conducted through a survey. A total of 63 students were selected purposively when all of the students who take core courses of the program, BBM3413 Research Methods in Malay Language have been asked to answer the questionnaire. A set of questionnaires containing nine open-ended questions and 54 questions using ordinal scales of semantic difference types were distributed. However, for the purpose of writing this paper, only the section that discusses the selection of fields of study while filling out applications for further study namely the knowledge of Malay language job, career in the field of language to be pursued and career awareness are used to address the following objective:

1. To identify the students' awareness of the scope of the Malay language and career potential in their field of study.

There are four research questions that want to be answered through this study, namely:

1. Do students choice Malay language program?

2. How well does students know the scope of a career in Malay languages?

3. What kind of career would be pursued after completing studies in Malay language program?

4. Do students believe that the Malay language has a huge potential in terms of career opportunities?

To get more in-depth information, a total of 27 students also voluntarily answered questions openly through the WhatsApp application, which is a question regarding the selection factors of university study programs. Therefore, the data of this study were analyzed using descriptive statistics, namely percentage, frequency, mean and standard deviation for the questionnaire. Meanwhile, the formation of the theme was made on the data of interviews conducted among students.

In total, 52(82.5\%) female students and 11(17.5\%) male students were involved in this study. In terms of the semester of study, the students who are the respondents of this study are in the fifth semester of their studies. The majority of respondents are Malays when a total of $60(95.2 \%)$ were in this group and only 3(4.8\%) were of the other races, the natives of Sabah/Sarawak and one Indian.

\section{Findings}

To answer the question regarding the selection of the current study programs, respondents were asked to state the choice of the Malay Language and Linguistics program out of eight programs, when filling out applications for Unit Pusat Universiti (UPU), the Ministry of Higher Education. In the UPU application, students can choose up to a maximum of eight fields of study that they want to further their studies. 
Table 1. Selection of the Malay Language and Linguistics Program

\begin{tabular}{lll}
\hline Selection & Frequency & Percentage \\
\hline 0 & 5 & 8.3 \\
1 & 15 & 25.0 \\
2 & 12 & 20.0 \\
3 & 7 & 11.7 \\
4 & 9 & 15.0 \\
5 & 6 & 10.0 \\
6 & 3 & 5.0 \\
7 & 2 & 3.3 \\
8 & 1 & 1.7 \\
\hline
\end{tabular}

According to Table 1, it was indicated that the field of study of Malay language appeared as the students' selection when more than half of the respondents, 34(56.7\%) chose this area as the first three options to study in higher education institutions. When asked in depth about the selection, the students said this election due to their interest of language as this is fascinating field to be studied in greater depth They learned that the responsibility and awareness of the country's official language as a mother tongue of the people deepens.

Students who answer this question through WhatsApp stated that it is due to interest, that this field becomes the first choice when filling out the university admission. It is suggestedin the following passage:

This program is my first choice. This is because, I was already very interested in the subject of the Malay language and literature in schoolso, this is definitely my top choice. (R11)

In addition, this interest may also arise during the study of the Malay Language subject at school either since the primary or secondary school. This interest continued until the tertiary level. In addition, there were some respondents who consider that studying the Malay language in higher education can improve and expand the official language of the country in the eyes of the world. This shows that respondents have a spirit of love and hope that the national language of Malay continues to develop into an international language. This is evidenced by the following passage:

I originally did take the language field starting from Form Six (STPM). (R15)

This program is the first choice because I am very interested in languages other than English since the schooling days. Next, the selection of the program is also a key field to improve and develop the Malay language ability to a higher level. God willing. (R27)

The respondents admitted that learning Malay language is fun. Through language learning at the tertiary level, they can get to know the race and culture. According to the respondents of the study, there is a variety of languages in the world that attracts them to take this field. This is proven in the following statement:

I feel that the Malay language is fun to venture into the field and we are able to recognize people and our culture as we learn our own language. (R21) 
I really want to venture into the field of language where I am very interested in the diversity of languages available in this world. (R22)

Respondents have the awareness to deepen their mother tongue driven by a sense of responsibility to change negative perceptions among a handful of people in this country as follows:

I am interested in deepening my knowledge of my own mother tongue. Also, I would like to add to the knowledge of the Malay language as many of our fellow citizens often degrade their own mother tongue so that the Malay language is considered to have less job opportunities. After I deepened my knowledge in this field,I was able to refute such statements. (R18)

The second factor Malay language and linguistics becomes the selection of respondents taking this field in higher education is due to the area of interest in them. This respondent stated that this field would be his first choice along with the interest in the Malay Language subject since high school. In fact, these respondents were offered the same course at two other public universities. This indicates that this respondent chose the language field as the first choice when filling out the university admission form.

Yes. Because I am interested in BM from my STPM. Therefore, linguistic Malay is my first choice. This is because, the field of language is very interesting, especially phonology and dialectology courses. In fact, I was also offered the same course at UM and UKM. (R1)

Next is the awareness of the respondents about the importance of learning and deepening this linguistics. Respondents are considered as citizens of this country who uphold the Malay language as the official language of the state, and its citizens need to learn and uphold the national language of the country. In fact, respondents were also agreeing with the opinion that learning the Malay language at the tertiary level has various advantages and interests.

This program is the top choice because I saw the Malay language as a field of science that is very important to me as a Malay Malaysians. This is because the Malay language is the native language of our own. Therefore, my affection towards the Malay language is thickened and feel compulsory to be studied. Therefore, the choice I made in this field as the main choice is right because there are various interests and benefits to it.. (R16)

These findings clearly show that the Bachelor of Arts in Malay Language and Linguistics at the Faculty of Modern Language and Communication, Universiti Putra Malaysia student studying to the courses of choice. However, there are $3(5.0 \%)$ students who were making this program as their last choice, namely as the seventh and eighth choice in the UPU form. In addition, there are $5(8.3 \%)$ students who did not choose this field, but continued their studies due to supply factors. Study respondents admit that the field they are studying now is not of their choice due to their ambition and interest factors. A number of the respondents said that they aspire to be an educator and are more interested in learning the field of language offered under the Faculty of Educational Studies. Apart from that, the respondents also said that their ambition is to become a lecturer but the field of language they are studying now is not their main choice. However, it may be the lack of exposure to career prospects in the field of study that cause these students to have 
such an impression. Meanwhile, R17 acknowledged his ambition and interest in sports activities that made this respondent applied the Physical Education program. Instead, he was offered a language program. However, this respondent is still active in sports and represents Universiti Putra Malaysia in volleyball. R24 and R26 say that they are more interested in furthering their studies in the field of economics or business management.

Honestly, my first option is the Malay language education. I have got the fifth option. This program is not my first choice because of my ambitions. My ambition is to be a lecturer in education. Nevertheless, life planning is constantly changing and life must go on. (R3)

This is because my first course of choice to enter Universiti Putra Malaysia is Physical Education. This is because, before continuing my studies at UPM, I studied sports science at Tunku Mahkota Ismail Sports School and I have skills in that field. With this, I am also proud to be able to continue my studies in the Malay language to be able to give a new branch of science to me. (R17)

This program is not the first choice because my interest is more in the field of economics and management. (R24)

In addition, the lack of respondents' interest in the field of language education is also due to the clearer scope of work. Respondents view the scope of work in the field of education as clearer than the field of language currently studied. This is because students who follow the education program will be offered to be educators while the field of language requires them to find suitable job opportunities. This is as stated by R25:

It is not because I prefer English language education, it is because these fields have a clear scope of work than in the field that I learned today. (R25)

This R25 view may be due to negative perceptions and lack of knowledge of the community as well as the respondents themselves about career prospects in this field. This is as stated by R7:

Honestly the Malay Language and Linguistics is not my first choice. This is because I am often bombarded with the fact that this field has a small scope of work choice and is not economical. Even so, after getting an offer for a language program at UPM and a Fine Arts (Graphics) program at USM, I have researched the scope of my career by doing research and searching on websites and asking seniors who specialize in language at UPM. Apparently, they gave a positive response and this made me choose to continue my studies in the field of language at UPM. After continuing their studies in this field of language, it turns out that the perception of the people who take it lightly by stating that this program is not productive is not true at all. During the study in this program, students have studied various branches of language such as psycholinguistics, sociolinguistics, semantics, phonology and stylistics. Thus, this combined knowledge can provide opportunities for students to venture into various fields of employment in the future. (R7) 
However, some respondents admitted that although the program offered was not an option, they received the opportunity to continue their studies with an open heart as in the following statement:

Bachelor of arts (Malay Language and Linguistics) is not my first choice. This program is the second choice in the program selection list because I am not very interested in the field of linguistics. However, this program opened up the opportunity for me to continue my studies, so I continued it even though I was a little less confident to follow this program. However, thank God I was able to follow it for 7 semesters and I was able to gain and learn a lot of very useful knowledge related to this language and linguistics. (R5)

In fact, after studying for several years, respondents began to think positively by not only accepting this field of study, but began to realize the diversity of knowledge learned in this field as the following statement:

My first and second option is the Malay language education and counseling. It's because I'm really interested in languages other than English since school, while the counseling field is my dream. But, this program became the third choice and there are two initial options that I chose in the program but I got this. While it is not education, I managed to enter the field of Malay language and it is gratifying. Even the field of counseling also exists in this program. It is an Introduction to Psycholinguistics course which also requires counseling skills. (R6)

To be honest, this course is not my top choice. The course of my previous choice was sports science education. However, this is my livelihood and eventually I could accept and begin to fall in love with the course of language and linguistics Malay is my native language. (R8)

There are respondents who choose this field when filling out the university admission form just to fill the list of options. Respondents admitted that, although the field of language is not their preference, they chose this field on the grounds of completing the course selection space found in the form.. This may be because their achievements meet the scope of the option. In fact, R20 admits that the selection of this field is due to the name of the program that looks great and attractive to him.

The program was not my first choice, in fact I did not expect to continue my studies in this field. Honestly, I chose this linguistic course just to fill in the blanks. I actually want psychology or counseling course because I am interested in those. However, my qualification is more to this course. Alhamdulillah, my studies in this cost are made easier.Through the course of linguistics, I also find that, to some extent it helps me to be more sensitive to the utterances and behaviors shown by every individual around me. People of this language should be admired by the people. (R12)

Bachelor of Malay Language and Linguistics is my third choice. I chose this program because its name looks so grand and interesting. In fact, my inclinations and interests are 
more focused on the field of counseling. (God willing, I will continue my undergraduate counseling studies later. (R20)

Finally, due to the factor of not getting a place in other universities the study respondents accepted this offered program as follows:

I only meet the UPU requirements which require me to select one program for each research university. This selection is done randomly because I have set some other programs related to the field of computing, which I have chosen based on the propensity of my matriculation exam results. This selection was made because I considered the words of my lecturers who gave opinions to choose in different fields for each university choice, to increase the probability of being accepted into the university. (R19)

I am the only student who has the opportunity to study here. After not getting a place in another university, I just chose to continue my studies here. (R23)

It can be concluded that among the factors that drive the choice of language field among study respondents is interest asthis field is interesting and important to learn. On the other hand, respondents did not choose this field due to their ambition factors, the negative stigma of society towards the scope of work in the field of language, not getting a place in another university and choosing it to fill the list of options in the university admission form alone.

To answer the question of how well students know the scope of a career in Malay language, a question is asked. This information was obtained through open questions, when students are free to list the types of jobs in this field that are known to them. As a result, students have listed between one and four careers. Students who were able to state at most, that is four careers, makes a total of 29(48.33\%) in this group. This was followed by three careers, namely $14(23.33 \%)$ and two options of $12(20.00 \%)$. Meanwhile, 5(8.33\%) students listed one career in languages other than English are known to them. In general, based on these findings it can be stated that the students of this fifth semester do have knowledge of the scope of career in this field of study while many students can list three and four types of careers.

Next, in terms of the types of careers that they will pursue after graduation, students are found to have listed 10 types of careers as shown in Table 2.

Table 2. Types of Occupations to be Entered

\begin{tabular}{lll}
\hline Job Type & Frequency & Percentage \\
\hline Teacher/Lecturer & 27 & 42.86 \\
Terminologist & 5 & 7.94 \\
Editor & 10 & 15.87 \\
Writer & 5 & 7.94 \\
Translator & 2 & 3.17 \\
Publisher & 2 & 3.17 \\
Government official & 1 & 1.59 \\
Interpreter & 1 & 1.59 \\
Administrative officer & 1 & 1.59 \\
News presenter & 1 & 1.59 \\
Not sure & 8 & 12.69 \\
\hline
\end{tabular}


Based on Table 2, it was found that most students want to be involved in the world of education while a total of $27(42.86 \%)$ are interested in becoming teachers and lecturers. This is followed by a career in the field of editor or editing as a sum of 10(15.87\%) are interested in venturing into this field. Students know the types of careers available in accordance with their field of study has listed their career as an editor, author, translator, publisher and careers in the Malay language terminology. However, the number of students who want to make this field their career is small. Although it is undeniable, students of this program can venture into the field of education such as becoming a tuition teacher and furthering their studies to the level of doctor of philosophy to become a lecturer. Somehow, careers such as language planners, language researchers, correspondence agents and so on are more appropriate to their field of study at university . In fact, there are $8(12.69 \%)$ who are unsure about their future careers. This is because this study program is not their choice, making them not to have a career plan in this field. Supposedly, after furthering their studies in this field, students should have the effort to do research on the scope of career in the field of language.

Although students are not very clear with their careers in the field of language that they will pursue after graduation, students are found to have high confidence in the potential of the field of study in providing bright career opportunities to them. This can be proven based on the following Table 3:

Table 3. Confidence Level of Careers Potential in Malay Language Studies

\begin{tabular}{lllll}
\hline No. & Item & Mean & SD & Level \\
\hline 1 & I know a career in Malay language. & 3.76 & 0.89 & High \\
2 & The field of Malay language has great potential. & 4.22 & 0.77 & High \\
3 & It is not difficult to get a job in this field. & 3.46 & 0.89 & Moderate \\
4 & The field of language for me has various career prospects. & 3.90 & 0.82 & High \\
5 & Students in this field obtain suitable employment. & 3.63 & 0.81 & Moderate \\
6 & Language field students can also succeed like other fields. & 4.30 & 0.69 & High \\
7 & The field of science and technology is more capable of generating & 3.79 & 0.94 & High \\
& national development. & & & \\
8 & Malay knowledge that I learned will help me get a good career. & 4.16 & 0.81 & High \\
9 & I will get a job in this field after graduation. & 3.87 & 0.87 & High \\
\hline Overall & 3.92 & 0.57 & High \\
\hline
\end{tabular}

There are nine items have been constructed to measure this aspect using ordinal scales of semantic difference types, with a scale between 1 to 5 as a weighting of item agreement. Levels of agreement on items are divided into three, namely low, medium and high. Mean values between 1.00 to 2.33 are categorized as low levels of agreement, mean values between 2.34 to 3.67 are categorized as moderate and mean values between 3.68 to 5.00 are categorized as high levels of agreement.

The respondents that believe the Malay language has huge potential recorded such values. $(\mathrm{M}=4.22 ; \mathrm{SD}=0.77)$. Meanwhilerespondentd who think students in the field of language can also be managed as other areas recorded these values. $(\mathrm{M}=4.30 ; \mathrm{SD}=0.69)$ Respondents who are confident that the language learned will help them achieve a good career makes up these values. $(\mathrm{M}=4.16$; $\mathrm{SP}=0.81)$. Overall, the study respondents consisting of students in this field of language have a high level of confidence in the potential of a career in the field they are studying by recording these values. $(\mathrm{M}=3.92 ; \mathrm{SP}=0.57)$. However, they have a moderate level of confidence in terms of appropriate employment for language field students. $(\mathrm{M}=3.63 ; \mathrm{SP}=0.81)$ 
Meanwhile, the view that it is not difficult to obtain employment in language field recorded these values. $(\mathrm{M}=3.46 ; \mathrm{SP}=0.89)$.

\section{Discussion}

The results showed that more than half of the samples involved in this study, a total of 34 (56.7\%) chose the Malay language and linguistics as the main option. Students surveyed also showed a high level of knowledge about careers in the Malay language which they learned when it recorded a mean value of 3.92 with a standard deviation of 0.57 . Students have also listed a total of 14 careers in the language fields they know. However, the issue of job awareness still needs to be given attention because as many as 29 (43.3\%) students who are the sample of this study continue their studies in their non-chosen field. This matter needs to be given serious attention at the secondary school education level again so that students are educated to pursue their future ambitions or careers based on their academic achievements and not simply learn to pursue A total in exam results. Although the results of the interviews showed that the se students admitted to being interested in the field of language, but certainly this interest took a long time and not all students managed to form an interest in the field of study at the tertiary level. Therefore, it is better if career targets are set as early as possible to enable students to achieve those career targets in accordance with the application for further studies at the tertiary level.

\section{Conclusion}

Overall, these findings indicate that the majority of Malay students in Universiti Putra Malaysia had a positive response and a high level of awareness of careers in the field of study. Although more than half of the respondents chose Malay language as the first choice, the amount of $43.3 \%$ of respondents that further studies in this field as the fourth to eighth option offered in their study needs to be given attention as well. This is to allow students to have the knowledge of a career in Malay language. Students have a high level of knowledge, but their chosen career is as only as a teacher and lecturer. Based on a review of the program's curriculum, graduates of Malay Language and Linguistics program is expected to have a career as a designer of language, language editors, translators, creative writers, screenwriter, professional writer, researcher of language, literary agents, author copywriter, and publisher. Therefore, it is important for students to plan their future career from the beginning and seriously study the scope and career prospects in this field so that the field of study involved is in their future career development. Students should have had career options as early as form four to enable them to focus on the field and focus on pursuing a career of interest (Jusoh et al., 2019).

Difficulty in making career choice decisions is an issue that is often experienced by individuals (Mohd Ibrahim et al., 2015). Although thought, interest and choice of career can appear as early as school age until after retirement throughout life (Mohamed Ashari et al., 2014), it is important that career knowledge is applied from the beginning to enable students to plan their education . Even though the study showed that the knowledge of students' career is still not widely studied, students pursuing this field still have time to think about careers in line with their study and a clear understanding about the prospects of a career in the Malay language they learned at university now.

This is in line with the opinion of Bujang and Yusuf (2015) who say that each individual has potential and talents that can be developed and enhanced. Therefore, by identifying the diversity of careers that can be pursued in the fields of Malay language, students can also see the potential and develop this potential. Career is the main activity and it is the activity that determines 
the pattern of life of the individual, which determines the satisfaction in the field ventured (Ibrahim et al., 2017). For that, students need to wisely plan appropriate career options by leveraging the field they have studied. An awareness needs to be applied that job opportunities in the current market are still wide open and never closed at all because this field of language and linguistics is so unique, constructive and relevant to the reality of current jobs and services (Razak, 2007). There should be no rumors saying that language graduates do not sell in the job market (Ahmad, 2013). Students and the community need to be aware that language is a medium to acquire and apply knowledge (Wan Yusoh, 2013). Without language, knowledge will not be able to be obtained and disseminated. Therefore, it is important for students to take the field either on their own choice or by offer to understand the potential of the Malay language as their career path. Next is, the interest to learn this field in depth.. The ability of the Malay language as an international language in a globalized world depends on the willingness of practitioners of Malay to use it as the language of science (Zubir et al., 2012) and it will be weakened if the function is not developed in line with in science and technology even though it was once one of the foremost languages in the world (Ghani, 2002).

Declaration of conflicting interest

The authors state that there is no conflict of interest concerning the publication of this article.

Funding acknowledgement

This research was conducted using the Grant Universiti Putra Malaysia in 2017 approved funding for a research topic "Perception of Students Against Potential and Prospects Careers in Malay Language".

\section{References}

Adam, R. (2014). Pendaulatan Bahasa Melayu sebagai Bahasa Kebangsaan dan Bahasa Ilmu di Malaysia: Sejarah dan kedudukan masa kini. Retrieved from http://dspace.unimap.edu.my/xmlui/bitstream/handle/123456789/34596/GENERAL\%20P APER 1.pdf?sequence $=1$

Ahmad, M. H. (2013). Mencipta Kerjaya Melalui Bahasa Melayu. Februari, Darihal Bahasa. Dewan Bahasa.

Ali, M. H., Ismail, A., Suleiman, N. \& Tajuddin, M. A. (2016). Faktor pemilihan kerjaya di kalangan pelajar Universiti Kebangsaan Malaysia: satu panduan untuk industri. Jurnal Personalia Pelajar 19(2): 9-15.

Ashari, M. Z. H., Rasul, M. S. \& Azman, N. 2014. Hubungan individu, persekitaran dan kebolehsesuaian terhadap pemilihan kerjaya pelajar sistem pensijilan kemahiran Malaysia (SPKM): satu analisis kandungan. Jurnal Sains Humanika 2(1): 135-144.

Bujang, Z. \& Yusuf, Y. Z. 2015. Trait personaliti dan hubungan dengan prestasi akademik bakal guru di sebuah institusi latihan perguruan. Jurnal Bitara Edisi Khas (Psikologi Kaunseling) 8: 171-180.

Esa, A., Mohd. Yunus, J., \& Ab. Hadi, M. Y.. (2002). Keperkasaan Bahasa Melayu dalam Kurikulum pendidikan Teknik dan Vokasional: Satu kajian kes di Institusi Pendidikan Teknikal di Malaysia. Prosiding Antarabangsa Pengajian Melayu Beijing ke-2. Kuala Lumpur: Dewan Bahasa dan Pustaka. pp 35-48.

Ghani, Y. (2002). Bahasa Melayu dipinggirkan bangsa sendiri, kata sasterawan negara. Retrieved from https://www.malaysiakini.com/news/12542 
Hassan, A. (2009). Bahasa Melayu di persimpangan: antara jati diri dengan rempuhan globalisasi. Kemanusiaan 16: 59-81.

Hassan, H. (2018). Martabatkan Bahasa Melayu ke Peringkat Antarabangsa. Retrieved from https://www.bharian.com.my/rencana/sastera/2018/04/418798/martabatkan-bahasamelayu-ke-peringkat-antarabangsa

Hameed, N. M. S. (2016). Terus perkasakan bahasa Melayu. Retrieved from http://www.utusan.com.my/rencana/terus-perkasakan-bahasa-melayu-1.206875

Ibrahim, N. I., Ibrahim, M. A. \& Abdul Aziz, S. F. (2017). Hubungan antara gaya asuhan ibu bapa dengan pemilihan kerjaya dalam kalangan pelajar universiti. e-Bangi. Special Issue 3, 1-11.

Ismail, A. \& Subramaniam, V. 2017. Pengajian bahasa di luar negara. Dewan Bahasa. Retrieved from http://dwnbahasa.dbp.my/?p=1825

Ismail, M. H.. (2012). Kajian mengenai kebolehpasaran siswazah di Malaysia: tinjauan dari perspektif majikan. Prosiding PERKEM VII, 2. pp 906-913.

Idris, M.M. R. (2013). Memartabatkan bahasa Melayu melalui pendidikan dan mendepani cabaran globalisasi. Malaysian Journal of Youth Studies (MJYS) 8: 207-222.

Ibrahim, M.N. L., Arip, M.M. A. S. \& Bustamam, M. N. (2015). Terjemahan, kesahan, dan kebolehpercayaan career thoughts inventory. Jurnal Sains Humanika 7(1): 31-41.

Jusoh, Z., Kiram, M.N. \& Said, R. (2019). Pengetahuan pelajar bahasa dan linguistik Melayu terhadap kerjaya dalam bidang bahasa Melayu. Proceeding of the International Conference on Social Sciences and Humanities, 8 - 9 Oktober, Parkcity Everly Hotel, Bintulu, Sarawak, Malaysia. pp 444-451.

Mahmud, M. I., Noah, M.S., Ahmad, J. \& Ahmad, W. M. (2016). Modul kesediaan kerjaya berdasarkan teori Cognitive Information Processing (CIP). Jurnal Kurikulum \& Pengajaran Asia Pasifik 4(3): 59-75.

Musa, H., Che Rodi, R. \& Muhammad, S. J. N. (2014). Pelestarian bahasa Melayu sebagai bahasa utama dalam persuratan dan pembudayaan ilmu, sains dan teknologi di rantau Ini. International Journal of Malay World and Civilisation (Iman) 2(2): 3-19.

Rasid, A. S. \& Abdullah, S. (2015). Mendaulatkan bahasa Melayu sebagai bahasa ilmu di institusi pengajian tinggi: Satu analisis. Journal of Human Development and Communication 4: 125134.

Razak, M. S. (2007). Potensi, Prospek Kerjaya Bahasa. Retrieved from http://mohamadsofee.blogspot.com/2007/12/potensi-prospek-kerjaya-bahasa.html

Sariyan, A. (2020). Hala Tuju DBP dalam Memartabatkan Bahasa Melayu Retrieved from http://klikweb.dbp.my/?p=4039

Sariyan, A. (2020). Merancang Masa Depan Bahasa Melayu. Retrieved from https://www.bernama.com/bm/tintaminda/news.php?id=1849617

Sariyan, A. (2009). Peranan bahasa dalam pembinaan insan dan pembangunan masyarakat hadhari. Jurnal Hadhari 1: 1-29.

Takari, M. (2013). Melayu: Dari lingua franca ke cultura franca Retrieved from https://www.researchgate.net/profile/Muhammad Takari/publication/256730080_MELAY U DARI_LINGUA_FRANCA_KE_CULTURA_FRANCA/links/00b7d523afa75aae10000 000.pdf

Wahab, A.K., Ma'alip, S., Yusuf, M. \& Harun, K. (2016). Kebitaraan program pengajian bahasa Melayu: persepsi dan harapan mahasiswa. Jurnal Melayu 15(2): 176-195.

Zubir, Z., Abdul Rahim, N. A., Zulkifli, N. S. \& Yusuf, W. S. (2012). Bahasa Melayu dalam arus globalisasi: keutuhan jati diri dan ketakatan budaya Melayu. Journal of Human Development and Communication 1: 129-135. 